\title{
Böbrek Hastalıkları ve Mikro Besin Ögeleri
}

\section{Renal Diseases and Micronutrients}

\author{
Alev Keser ${ }^{1}$, Esra Tunçer ${ }^{2}$
}

Geliş tarihi/Received: 12.02.2018 • Kabul tarihi/Accepted: 02.12.2018

\section{ÖZET}

Kronik böbrek hastalıkları, farklı mikro besin ögelerinin eksikliğine ya da toksisite yaratacak düzeyde fazlalığına neden olabilmektedir. Mikro besin ögeleri düzeylerinde meydana gelen bu anormallikler çeşitli nedenlere bağlı olarak gelişmektedir. Diyet kısıtlamaları ve anoreksiya bir mikro besin ögesinin yetersiz alımına yol açarken, diüretik kullanımı ve renal replasman tedavisi aşırı kayıplara neden olmaktadır. Ayrıca besin ögelerinin emiliminde değişiklikler meydana gelmekte ve metabolizmaları bozulmaktadır. Kronik böbrek hastalarının mikro besin ögesi gereksinmelerinin daha iyi anlaşılması, yüksek mortalite, artan ateroskleroz riski, inflamasyon, oksidatif stres, anemi, polinöropati, ensefalopati, halsizlik, kas krampları, kemik hastalıkları, depresyon veya uykusuzluk gibi vitamin ve mineral bozuklukları ile ilişkili birçok komplikasyon üzerinde etkili olabilir. Derleme olarak hazırlanan bu makalede, kronik böbrek hastalıklarının farklı evrelerinde mikro besin ögesi durumunun değerlendirilmesi ve gereksinmelere yönelik güncel bilgilerin paylaşılması amaçlanmıştır.

Anahtar kelimeler: Diyaliz, eser element, kronik böbrek hastallğl, mineral, vitamin

\section{ABSTRACT}

Chronic kidney diseases may lead to one to either deficiency or toxic excess of different micronutrients. Abnormalities of micronutrient levels in CKD develop for several reasons. While dietary restrictions and anorexia lead to inadequate intake of micronutrients, renal replacement therapy and use of diuretic cause excessive losses. Also, changes occur in the absorption of nutrients and their metabolisms are impaired. The better understanding of the micronutrient requirements of patients with chronic kidney disease may have impact on several complications associated with vitamin and mineral disorders such as high mortality, increased risk of atherosclerosis, inflammation, oxidative stress, anemia, polyneuropathy, encephalopathy, weakness, muscle cramps, bone diseases, depression or insomnia. This review is aimed to evaluate the status of micronutrients in different stages of chronic kidney diseases and to share the current information about the requirements.

Keywords: Dialysis, trace element, chronic kidney disease, mineral, vitamin

1. İletişim/Correspondence: Ankara Üniversitesi, Sağllk Bilimleri Fakültesi, Beslenme ve Diyetetik Bölümü, Ankara, Türkiye

E-posta: alevkeser@gmail.com • — https://orcid.org/0000-0003-2620-6747
2. Ankara Üniversitesi, Sağllk Bilimleri Fakültesi, Beslenme ve Diyetetik Bölümü, Ankara, Türkiye • • $\odot$ https://orcid.org/0000-0001-7151-842X 


\section{GíRiş}

Vitamin ve mineral eksiklikleri, dünya nüfusunun üçte birinden fazlasını etkileyerek büyük bir sağlık yükü oluşturmakta ve oldukça önemli komplikasyonlara neden olabilmektedir. Kronik böbrek hastalığı (KBH) olan bireylerde malnütrisyon önemli bir sorun olmakla birlikte, bozulmuş mikro besin ögesi durumu daha az farkına varılan bir komplikasyondur. Çoğu durumda, mikro besin ögesi eksikliği yavaş ilerler ve KBH'den ayırt edilemeyen klinik bulgulara sahiptir (1).

En uygun mikro besin ögesi düzeylerinin kardiyovasküler hastalı veya inflamatuvar durum gibi kronik komplikasyonların gelişmesine katkıda bulunduğuna yönelik kanıtlar, KBH’nin birçok komplikasyonunun, mikro besin ögelerinin biyoyararlanımındaki dengesizliğe bağlı olabileceğini düşündürmektedir. Mikro besin ögelerinin yetersiz alımı, ateroskleroz, inflamasyon, oksidatif stres, anemi, polinöropati ensefalopati, halsizlik, kas krampları, kemik hastalığı, depresyon, uykusuzluk ve erken ölüme neden olabilmektedir $(1,2)$.

Böbrek işlevlerinin bozulması, mikro besin ögelerinin veya metabolitlerinin toksisitesi açısından bir risk oluşturmakla birlikte, vitamin ve mineral yetersizliği de temel olarak endişe verici bir durumdur. Kronik böbrek hastalığında mikro besin ögesi eksikliği, diyet kısıtlamaları, iştahın azalması, komorbiditeler, eş zamanlı kullanılan ilaçlar, bozulmuş bağırsak emilimi, değişen metabolizma, idrar veya diyalizatla aşırı kayıplar, besin değeri yüksek olan yiyecekleri satın alma ve hazırlama güçlükleri veya yutma sorunları nedeniyle gelişebilir. Buna ek olarak yaşla birlikte mikro besin ögesi yetersizliği riski artar ve genellikle KBH olan bireyler ileri yaştadır $(3,4)$.

Mikro besin ögesi kayıpları kronik böbrek hastalığının tüm evrelerinde oluşabilir. Hastalığın erken evrelerinde, diüretik kullanımı ve/veya spesifik taşıyıcılar tarafından yetersiz geri emilim nedenleriyle mikro besin ögeleri idrar yoluyla kaybedilir. Son dönem böbrek yetmezliğinde, bu düşük molekül ağırlıklı maddeler, hemodiyaliz ve periton diyalizi sıvılarında rutin olarak bulunmadığı için diyaliz yoluyla uzaklaştırılma eğilimindedir. Diğer taraftan, su kaynaklı diyaliz sıvısında bu besin ögelerinin düşük düzeyleri de kandaki düzeylerinin artmasına ve hastanın vücudunda birikmesine neden olabilir (1).

$\mathrm{Bu}$ nedenlerle kronik böbrek hastalıklarının tedavisinde, mikro besin ögelerinin durumunun değerlendirilmesi ve buna göre tedavi stratejilerinin belirlenmesi oldukça önemlidir. Ancak, kronik böbrek hastalıklarında özellikle suda çözünür vitaminlere ve eser elementlere yönelik oldukça sınırlı veri olması nedeniyle mevcut rehberlerin içerikleri ve öneriler genellikle uzman görüşlerine ya da düşük düzey kanıtlara dayanmaktadır (1).

$\mathrm{Bu}$ makalenin amacı, diyaliz öncesi veya diyaliz tedavisi sırasında, farklı evrelerdeki kronik böbrek hastalıklarında mikro besin ögesi gereksinmelerine yönelik güncel bilgilerin paylaşılmasıdır.

\section{Mikro Besin Ögelerinin Diyetle Alımı}

Mikro besin ögelerinin diyetle alımı, beslenme yetersizliklerinin önlenmesinde rol oynayabilen değiştirilebilir bir etmenidir. Kronik böbrek hastalığında protein, fosfor veya potasyum alımını azaltmayı amaçlayan kısıtlamalar, diyetle diğer mikro besin ögelerinin yeterli miktarda sağlanmasını güçleştirmektedir (1,3). Özellikle potasyumun diyetle alımının kısıtlanması, C vitamininin yetersiz alımına, proteinin kısitlanması ise B grubu vitaminlerinin günlük önerilen düzeyin çok altında alınmasına neden olabilmektedir (Tablo 1) (3,4). 
Tablo 1. Farklı protein içeriklerine sahip diyetlerin tahmini vitamin içerikleri ile önerilen günlük alım miktarı* $(3,4)$

\begin{tabular}{lcccccc}
\hline & & \multicolumn{3}{c}{ RDA $^{*}$} & \multicolumn{3}{c}{ Günlük protein alımı (g/gün) } \\
\cline { 2 - 7 } Vitamin & Birim & Erkek & Kadın & $\mathbf{4 0}$ & $\mathbf{6 0}$ & $\mathbf{8 0}$ \\
\hline $\mathrm{B}_{1}$ vitamini & $\mathrm{mg}$ & 1.2 & 1.1 & 0.6 & 1.0 & 1.1 \\
$\mathrm{~B}_{2}$ vitamini & $\mathrm{mg}$ & 1.3 & 1.1 & 0.8 & 1.2 & 1.8 \\
$\mathrm{~B}_{6}$ vitamini & $\mathrm{mg}$ & 1.7 & 1.5 & 1.0 & 1.2 & 1.5 \\
Biotin & $\mu \mathrm{g}$ & 30 & 30 & 13.4 & 17.8 & 15.8 \\
Folik asit & $\mu \mathrm{g}$ & 400 & 400 & 260 & 290 & 320 \\
$\mathrm{~B}_{12}$ vitamini & $\mu \mathrm{g}$ & 2.4 & 2.4 & 2.3 & 3.2 & 5.1 \\
C vitamini & $\mathrm{mg}$ & 90 & 75 & 86 & 87 & 88 \\
\hline
\end{tabular}

* RDA: Önerilen günlük alım miktarl (51-70 yaş bireylere yönelik öneriler)

Buna ek olarak, hastaların beslenme ve inflamatuvar durumu, diyaliz yeterliliği ve rezidüel böbrek işlevinin korunması mikro besin ögesi alımını etkileyebilmektedir (1,3). Ancak, vitaminlerin vücut depolarının büyüklüğü farklı olduğu için diyet kısıtlaması (tedavi amaçlı veya istemsiz) ve diyaliz süresinin etkisi, bu depoların büyüklügüne bağlı olarak bir dereceye kadar etki edecektir (Tablo 2) (3).

Tablo 2. Bazı vitaminlerin vücut depo süresi (3)

\begin{tabular}{ll}
\hline Vitamin & Ortalama depo süresi \\
\hline $\mathrm{B}_{1}$ vitamini & $4-10$ gün \\
$\mathrm{B}_{2}$ vitamini & $3-4$ ay \\
$\mathrm{B}_{6}$ vitamini & $3-4$ ay \\
Folik asit & $1-1.5 \mathrm{yll}$ \\
$\mathrm{B}_{12}$ vitamini & $3-5 \mathrm{yll}$ \\
$\mathrm{C}$ vitamini & $3-4$ ay \\
A vitamini & $1-2$ yll \\
D, E, K vitamini & $2-6$ hafta \\
\hline
\end{tabular}

\section{Kronik Böbrek Hastalığının Farklı Evrelerinde Mikro Besin Ögelerinin Durumu}

\section{Suda Çözünen Vitaminler}

\section{Tiamin (B vitamini)}

Tiamin eksikliği periton diyalizi alan hastalarda daha sık olup kardiyomiyopati, polinöropati ve Wernicke ensefalopatisi ile ilişkilidir (1). Kronik böbrek hastalığında tiamin eksikliğinin görülme nedenleri, diyet kısıtlamaları, malnütrisyon, uzun dönem diüretik tedavisi alma, diyalizat ile kayıp, üremik toksinlerin varlığıdır (5). Eritrosit transketolaz aktivite katsayısı, tiamin durumunun iyi bir işlevsel göstergesidir ve bu değerin $<1.20$ olması tiamin eksikliğinin olmadığını ifade eder (2). Mevcut öneriler günde 1.1-1.2 mg tiamin desteğinin gerekli olduğunu göstermektedir (3). Ancak bununla ilgili kapsamlı bir çalışmaya rastlanmamıştır.

\section{Riboflavin ( $B_{2}$ vitamini)}

Riboflavin eksikliği, anguler stomatit, keylozis ve glossit ile karakterizedir ve genellikle diğer vitamin eksiklikleri ile birlikte ortaya çlkar. Riboflavin durumu, eritrosit glutatyon redüktaz aktivite katsayısı ile belirlenir ve bunun $>1.3$ olması riboflavin eksikliğini gösterir (3).

Diyalize girmeyen hastalarda yapılan bir çalışmada, hastaların \%8'inde riboflavin eksikliği olduğu, bu hastaların protein alımları azaldıkça riboflavin eksikliği prevalansının arttığı ve \%41’lere yükseldiği saptanmıştır (6). Bunun yanında diyaliz alan hastalarda riboflavin eksikliğinin daha seyrek olduğu bildirilmiştir. Riboflavin desteği için güçlü bir kanıt bulunmamakla birlikte, destek alan hastalarda yeterli olduğu belirtilmektedir (3). Diğer yandan <0.6 g/kg/ gün protein alan hastalara riboflavin desteğini öneren araştırmacılar vardır (2).

\section{Niasin ( $B_{3}$ vitamini)}

Kronik böbrek hastalığında görülen ve aynı zamanda kardiyovasküler hastalıklar için risk etmenleri 
olan dislipidemi ve yüksek plazma fosfat düzeyi tedavisinde niasinin yararlı olabileceği belirtilmiştir (7). Niasin, oksidatif stresi ve bağırsaklardan fosfor emilimini azaltır, trigliserit düzeyinde azalma ve yüksek dansiteli lipoprotein (HDL)-kolesterol işlevinde iyileşme sağlar (8). Altı ay boyunca verilen düşük doz niasin desteğinin (500 mg/gün) KBH’li bireylerde dislipidemiyi iyileştirdiği, serum fosfor düzeyini azalttığı ve glomerüler filtrasyon hızında (GFH) artış sağladığı saptanmıştır (9).

Fosfor kısıtlı (800 mg/gün) ve düşük proteinli (<0.6 $\mathrm{g} / \mathrm{kg} / \mathrm{gün}$ ) diyet uygulayan $\mathrm{KBH}$ hastalarında niasin eksikliği görülebilir (2). Diyaliz hastalarında ise niasinin birikme potansiyelinin olduğu ancak bu popülasyon için uzun dönemde güvenli alımının ne olduğu konusu net değildir (3).

\section{Pantotenik asit ( $B_{5}$ vitamini)}

Pantotenik asit, hemen hemen tüm besinlerde bulunduğu için eksikliğine seyrek olarak rastlanır. Düşük proteinli diyet uygulanan KBH'li bireylerde diyetle yetersiz alındığı yönünde bulgular mevcuttur (2). Diyalize giren bireylerde pantotenik asit düzeyinin normal olabileceği ve GFH'si düşük veya son dönem böbrek yetmezliği olan hastalarda besin desteği olarak kullanımına yönelik bir öneri yoktur (3).

\section{Piridoksin ( $B_{6}$ vitamini)}

Hemodiyaliz alan hastalarda piridoksin eksikliği \%24-56 oranında görülmektedir. Kronik böbrek hastalığında görülen piridoksin eksikliğinin nedenleri arasında, diyetle alımında ve bağırsak emiliminde azalma, diyalizat ile kayıp, ilaç etkileşimleri (izoniazid, tiroksin, iproniazid, teofilin, hidralazin, kafein, penisillamin, etanol ve oral kontraseptifler), piridoksal 5'-fosfat degradasyonunda artış yer alır (10). Piridoksin düzeyinde azalma hiperhomosisteinemi ile ilişkilidir (11). Vücutta piridoksin düzeylerinin yeterliliği, eritrosit glutamik pirüvik transaminaz (EGPT) enzim aktivitesi ve indeksi ile değerlendirilmektedir. EGPT indeksinin $>1.25$ olması piridoksin eksikliğinin bir göstergesidir. Özellikle Evre $\geq 3$ olan $\mathrm{KBH}$ hastaları piridoksin eksikliği açısından daha büyük risk altındadır. $\mathrm{Bu}$ nedenle uygun şekilde piridoksin desteğinin yapılması önerilmektedir (2). Piridoksin desteğine yönelik öneriler, hiç yapılmaması gerektiği ile 10-50 mg/gün arasında değişmektedir. Piridoksal5-fosfat düzeyini normalize etmek için yüksek akımlı hemodiyalizde ve periton diyalizinde hastalarda günlük $\mathrm{B}_{6}$ vitamini alımının $10 \mathrm{mg}$ olmasının yeterli olduğu öne sürülmektedir $(3,10)$.

\section{Folik asit (Folat, $\mathbf{B}_{9}$ vitamini)}

Bağırsak emiliminde bozulma, ilaç etkileşimleri (barbitüratlar, primidon, sikloserin, pirimetamin, difenilhidantoin, triamteren, metotreksat, trimethoprim, mysoline, pentamisin, salisilazosülfapiridin, etanol), diyalizat kayıları nedenleriyle KBH'da folik asit eksikliği görülebilir (11). Folik asidin, plazma proteinlerine zayıf bağlanması her diyaliz seansı sırasında önemli kaybına (bir seansta \%37) neden olur (1).

Ayrıca, Evre 3 ve Evre 4 KBH'li bireylerde folik asit eksikliğinin potasyum kısıtlı diyetle ilişkili olabileceği bildirilmektedir (12). Diyaliz öncesi Evre 4 ve Evre 5 arasinda olan KBH'li hastalarda, folik asit metabolizmasının değiştiğiancak değişimin nedeninin ve zamanının belirlenmediği ifade edilmiştir (2).

Folatın çok yüksek miktarda (>1000 $\mu$ g/gün) alınması, $\mathrm{B}_{12}$ vitamini ile ilişkili anemiyi düzelterek tanının geç konulmasına neden olabilir ve folat desteği $B_{12}$ vitamini eksikliği olan hastalarda nörolojik bozulmayı hızlandirabilir (3).

Folik asit eksikliği, anemi gelişimine ve eritropoezi uyaran ajanların (ESA) direncine neden olan etmenler arasındadır (13). Hemodiyaliz hastalarında, serum ve kırmızı kan hücrelerinde folik asit düzeyleri düşebilir ve bu durum megaloblastik anemiye neden olabilir (11). Yeterli düzeyde folat alımı olmazsa, yeterli homosistein-metiyonin dönüşümü gerçekleşmez ve homosistein düzeyi yükselir. Hiperhomosisteinemi, son dönem böbrek hastalığında, kardiyovasküler morbidite ve mortalitenin bağımsız bir belirleyicisi olarak kabul edilmektedir. Böbrek metabolizmasının 
bozulması ve böbrek atılımının azalması nedeniyle KBH'li bireylerin yaklaşık \%85'inde hiperhomosisteinemi görülür (14).

Diyaliz öncesi dönem için en uygun ve güvenli günlük folat alım miktarı bilinmemektedir. Hemodiyaliz hastalarında ise folat desteğinin gerekli olmadığı önerilmekte, ancak hastaların \%10'unda eksiklik belirtilerinin görülmesi bu önerinin özellikle tahılların folat ile zenginleştirilmediği ülkelerde sorgulanması gerektiğini düşündürmektedir. $\mathrm{Bu}$ nedenle, en uygun yaklaşım, düşük dozlarda (2-7 mg/ hafta) folat desteğinin verilmesi yönündedir (3).

\section{Kobalamin ( $\mathrm{B}_{12}$ vitamini)}

Kobalamin eksikliği KBH'de seyrek rastlanan bir durum olup, genellikle ağır düzeyde beslenme bozukluğu olan hastalarda makrositoz ile kendini gösterir. Ayrıca nörolojik, hematolojik, bilişsel komplikasyonlara neden olur ve hiperhomosisteinemi ile ilişkilidir (15).

İleri yaşa bağlı olarak artan gastrik inflamasyon ve atrofi sonucunda gelişen hipokloridi, $\mathrm{B}_{12}$ vitamininin salınımını ve emilimini baskılar. Malabsorbsiyonun diğer nedenleri arasında, proton pompa inhibisyonu, immünolojik,intrinsikfaktör durumu,transkobalamin varyantları, postgastrik cerrahi, bağırsak hastalığı veya konstipasyon yer alır. Malabsorbsiyon, $\mathrm{B}_{12}$ vitamini desteği sağlanarak önlenebilir (3).

Mevcut önerilere göre, en uygun düzeyin korunabilmesi için $2.4 \mu \mathrm{g} /$ gün alınması yeterlidir. Diyaliz tedavisinden bağımsız olarak eksikliğinden korumak için özellikle yaşlı bireylere rutin olarak düşük doz $\mathrm{B}_{12}$ vitamini desteği önerilmektedir (3).

\section{Askorbik asit (C vitamini)}

Kronik böbrek hastalığında askorbik asit düzeylerinin, çok düşükten çok yükseğe kadar değişebilen farklı değerlere sahip olduğu bildirilmektedir (16). Bir diyaliz seansı sırasında yaklaşı \% 28-40 arasında askorbik asit kaybı gözlenebilmektedir (1). İntradiyalitik kayıplarla bu oranın \%60’a ulaşabileceği belirtilmektedir. Ayrıca askorbik asit hemodiyaliz sırasında kolayca dehidroaskorbik aside oksitlenebilmektedir (17).

Kronik böbrek hastalığında askorbik asit eksikliğinin görülme nedenleri arasında, potasyumdan sinırlı diyet tüketimi, düşük molekül ağırlığı ve suda çözünme kapasitesi nedeniyle diyalizata kolay geçmesi, mukozal demir birikimi nedeniyle yeterli düzeyde alınsa bile demir ile reaksiyona girerek gaita ile atılması yer alır (13).

Özellikle hemodiyaliz seansları uzun olan hastalara günde 60-100 mg askorbik asit desteği verilebilir (3). Ancak hiperoksalozis riskinde artış nedeniyle KBH'li askorbik asitin yüksek dozları önerilmemektedir (2). Çünkü diyaliz hastalarında oksalat düzeyleri normalden iki kat daha yüksektir ve askorbik asit desteğinden sonra yedi kata kadar yükselebilmektedir (1).

\section{Yağda Çözünen Vitaminler}

\section{A vitamini}

Son dönem böbrek yetmezliğinde, A vitamini düzeyleri yüksektir ve A vitamini desteği kontrendikedir (18). Özellikle, A vitamininin kanda taşınmasında görev alan retinol bağlayıcı proteininin katabolizmasının azalması, A vitamini düzeyinde artışa neden olabilir (2). Diyalize girmeyen $\mathrm{KBH}$ ve son dönem böbrek yetmezliği olan hastalarda, yüksek A vitamini düzeyi ile yüksek serum kreatinin düzeyi arasında bir ilişki olduğu için A vitamini desteği önerilmemektedir (18).

\section{D vitamini}

Böbreklerde 25(OH)D vitaminini 1,25(OH)2D vitaminine dönüştüren, 1 alfa hidroksilaz enzim aktivitesinin böbrek hastalıklarında azaldığı belirtilmiştir. Diyaliz tedavisi alan hastalarda $1,25(\mathrm{OH})_{2}$ kolekalsiferol ile 25(OH) kolekalsiferol düzeylerinin düşük olduğu saptanmıştır (19). Kronik böbrek hastalığında, 25(OH)D eksikliğinin/ yetersizliğinin görülme nedenleri ve risk etmenleri, yaş, kadın cinsiyet, adipozite, proteinüri, yetersiz fiziksel aktivite düzeyi, diyabet, azalmış D vitamini 
reseptörü, periton diyalizi, 25(OH)D’nin tübüler geri emiliminde bozulma, D vitaminin deri sentezinin azalması, sekonder hiperparatiroidizmde karaciğer sitokrom p450 izoformunun azalması, kalsinörin inhibitörü kullanımıdır (20).

D vitamini eksikliği/yetersizliği KBH'de görülen sekonder hiperparatiroidizm ve kemik döngüsü belirteçlerinde artış, düşük kemik mineral yoğunluğu, obezite, insülin direnci, metabolik sendrom, kas zayıflı̆̆ ve düşme tehlikesi, sol ventrikül hipertrofisi ve ateroskleroz, vasküler kalsifikasyon ve arteriyel sertlik, bilişsel bozukluk, böbrek hastalığının ilerlemesi ve mortalite sonuçlarıyla ilişkilidir (20,21). $\mathrm{Bu}$ nedenlerle $\mathrm{D}$ vitamini eksikliği/yetersizliğinin tedavi edilmesi gereklidir.

Evre 3-5 arasında olan KBH'li bireylerde 25(OH)D düzeylerinin ölçülmesi ve daha sonra bu değerlere ve tedavi edici müdahalelere göre testin tekrarlanması önerilmektedir. D vitamini eksikliği/yetersizliği, genel popülasyon için önerilen tedavi stratejileri kullanılarak düzeltilmelidir. Ayrıca diyalize girmeyen, Evre 3 ve Evre $5 \mathrm{KBH}$ olanlarda kalsitriol ve D vitamini analoglarının rutinde kullanımı önerilmemekle birlikte, şiddetli ve ilerlemiş hiperparatiroidizmi olan Evre 4 ve Evre 5'deki KBH olan bireylerde D vitamini desteği düşünülebilir (22).

\section{E vitamini}

Sağlıklı kontrollere kıyasla KBH'li bireylerde Evitamini düzeyinin farklı olmadığı ancak diyetle E vitamini alımının azalabildiği bildirilmiştir (2). Ayrıca, diyaliz seansı sonunda E vitamini düzeyinin azalabileceği ve bu durumun diyaliz sırasında artmış oksidatif stres ile ilişkili olabileceği de belirtilmektedir. Diğer yandan E vitamininin rejenerasyonu için gerekli olan $\mathrm{C}$ vitamini düzeyinin azalması da $\mathrm{E}$ vitamini eksikliğine neden olabilir (13). E vitaminin metaboliti olan karboksietil hidroksikroman düzeyi, böbrek işlevinin azalması (kreatinin klirensi $45 \mathrm{~mL} /$ dakika, Evre 3) ile birlikte serumda önemli düzeyde artar. $\mathrm{Bu}$ metabolitin birikmesi, üremik $\mathrm{KBH}$ olanlarda $\mathrm{E}$ vitamini işlevini bozabilir (23). Diyalize girmeyen Evre 2 ve Evre $5 \mathrm{KBH}$ olan bireylere normal düzey olan 15 IU/gün E vitamini önerilmektedir (2).

\section{K vitamini}

K vitamini vücuda diyetle alınabilmekle birlikte, bağırsak bakterileri tarafından da üretilebilmektedir. Üremi nedeniyle bağırsak mikrobiyotasının değişmesi, $\mathrm{K}$ vitamini üreten bakterilerin olumsuz yönde etkilenmesine, daha düşük üretime ve emilime yol açar. Bu nedenle, K vitamini eksikliği görülebilir (24). Antibiyotik kullanımı da bağırsak mikrobiyotasını etkileyerek bakterilerin $\mathrm{K}$ vitamini üretimini değiştirebilir (2).

$\mathrm{K}$ vitamini kemik matriks proteinlerinin karboksilasyonunda görev aldığı için ileri dönem KBH'de K vitamini düzeyinin düşük olması kemik hastalıklarının gelişmesine katkıda bulunabilir. Uzun süre antibiyotik tedavisi alan, protrombin süreleri uzamış olan kadınlara en az 90 mg/gün, erkeklere 120 mg/gün K vitamini desteği düşünülebilir (2).

\section{Eser Elementler}

\section{Demir}

Kronik böbrek hastalığı olan hastalarda yüksek gastrointestinalkankaybısıklığıgözönünealındığında, eser elementler arasında demir eksikliği ve buna bağlı olarak gelişen anemi en önemli sorunlardan biridir. Kronik böbrek hastalarında, özellikle son dönem böbrek yetmezliği hastalarında yıllık demir kaybı yaklaşık 1-3 g kadardır (25). Böbrek yetmezliği olan hastalarda anemi gelişiminin altında yatan en önemli etmem, eritropoietin düzeyinin azalmasıdır. Ayrıca üremik toksinler, kırmızı kan hücrelerinin yarılanma ömrünü kısaltabilir ve kemik iliğinin eritropoietine yanıtını azaltabilir. Bu hastalarda gastrointestinal sistemin normal yapısınin bozulması ve kullanilan bazı ilaçlar (fosfor bağlayıcılar) nedeniyle diyet demirinin emilimi bozulmuştur. Buna ek olarak, üremi ile ilişkili trombosit işlev bozukluğuna bağlı kronik kanamalar, hiperparatiroidizme sekonder kemik iliği fibrozisi, diyalizör ve setlerde kan kalması, demirin diyalizörler tarafindan tutulması, sık kan 
alınması ve alüminyum fazlalığı gibi nedenler kaybın yüksek olmasına katkıda bulunmaktadır (26). Ayrıca dolaşımdaki hepsidin düzeylerinin KBH'de artmasına bağlı olarak demir kullanımının bozulmasının da anemi gelişimine aracılık etmektedir (13). Bu nedenle, KBH'nin her evresinde aneminin uygun tedavisi önemli bir gerekliliktir. Henüz anemi tanısı almamış Evre $3 \mathrm{KBH}$ hastaları yılda en az bir kez, diyaliz almayan Evre 4 ve Evre 5 KBH hastaları yılda en az iki kez, Evre $5 \mathrm{KBH}$ olan hemodiyaliz ve periton diyalizi alan hastalar ise her üç ayda bir anemi açısından değerlendirilmelidir (27).

Son dönem böbrek hastalığı olanların hematokrit düzeyini \%20-25'in üzerinde tutmak için rekombinant eritropoietin uygulanmaktadır. Demirin tükenmesi eritropoietine yanıtı bozacağı için eritropoietin kullanımı demir depolarının değerlendirilmesini gerektirir. Hemodiyaliz veya sürekli ayaktan periton diyalizi (CAPD) ile tedavi edilen hastalara, demir eksikliği sıklığının yüksek olması nedeniyle demir desteği yapılır. İntravenöz yola kıyasla oral demir desteği daha yaygın olarak kullanılır (28).

\section{Bakır}

Sağlıklı bireylere kıyasla serum bakır düzeyinin kronik böbrek yetmezliği hastalarında daha düşük olduğu saptanmıştır (29). Yapılan bir çalışmada $\mathrm{KBH}$ evresi arttıkça serum bakır düzeyinin arttığı bildirilmiştir (30). Başka bir çalışmada ise KBH'nin farklı evrelerinde serum bakır düzeyleri arasında anlamlı farklılık bulunmamıştır (31).

Bakır eksikliği seyrek görülmekle birlikte, malabsorpsiyonu ve aşırı çinko alımı olan bireylerde ortaya çıkabilir. Bakır eksikliği, anemi, hiperkolesterolemi, hipopigmentasyon, nötropeni, lökopeni, miyelodisplazi, nörolojik bulgular, osteoporoz ve iskemik kalp hastalığına neden olabilir (32).

Genelolarakböbrekyetmezliğiolan hastalar, uzunsüre parenteral yolla beslenmedikçe bakırın eksikliğinden ziyade, yüksek bakır düzeyine sahiptirler.

\section{Çinko}

Diyaliz tedavisi alan veya almayan kronik böbrek yetmezliği olan hastaların, plazma çinko düzeylerinin düşük olduğu bildirilmiştir. Çinko eksikliği, böbrek işlevlerinin azalması, proteinüri, proteine bağlı elementlerin kayıplarına yol açan gastrointestinal emilim değişiklikleri, inflamasyon, hipoalbüminemi ve diyaliz işlemi nedenleriyle ortaya çıkabilir (33). Çinko eksikliğinde, dermatit, lingual papiller atrofi, yaraların geç iyileşmesi, alopesi, nöropsikolojik bozukluklar, hipogonadizm, tat ve koku alımında azalma görülebilir. Bu semptomların bazıları çinko desteği ile iyileşebilir (32).

\section{Selenyum}

Kronik böbrek hastalarında serum selenyum düzeyi azalır. Bu duruma selenyumun yetersiz emilmesi, diyaliz sıvısı ve idrarla kaybedilmesi, anoreksiya, sınırlı protein alımı neden olabilir. Selenyum eksikliği, anemiye, miyopatiye, immün sistem işlev bozukluğuna, glutatyon peroksidaz eksikliğine, konjestif kardiyomiyopati ile karakterize olan Keshan hastalığının gelişimine neden olabilir (1). Selenyum desteğinin, glutatyon peroksidaz aktivitesini ve plazma selenyum düzeyini arttırdığı, hemodiyaliz hastalarının beslenme durumunu iyileştirdiği bildirilmektedir (34). Kronik böbrek hastalığında belirgin selenyum eksikliği riski olmasına rağmen, rutin selenyum desteği konusunda bir öneri bulunmamaktadır (1).

\section{Alüminyum}

Genellikle KBH'li ve diyaliz hastalarında plazma alüminyum düzeyi artmaktadır. Sağlıklı bireylerin serumundaki alüminyum düzeyi genellikle <10 $\mu \mathrm{g} / \mathrm{L}$ iken diyaliz hastalarında 20-40 $\mu \mathrm{g} / \mathrm{L}$ düzeyine çıkabilmektedir. $50 \mu \mathrm{g} / \mathrm{L}$ üzeri aşırı alüminyum yüklendiğini gösterir (35). Alüminyum birikimi ensefalopati, diğer nörolojik sendromlar, kemik hastalığı (özellikle osteomalazi), miyopati ve anemi ile sonuçlanabilir (36). 
Plazmadaki alüminyum düzeyi, diyalizatta bu eser elementin varlığına veya alüminyum içeren fosfor bağlayıcı ajanların kullanılmasına bağlı olarak yükselir. Son dönem böbrek yetmezliği olan hastalarda alüminyumun, idrarla atımının azalmasına ve gastrointestinal kanaldaki emiliminin artmasına bağlı olarak biriktiği belirtilmektedir. $\mathrm{Bu}$ nedenle, alüminyum içeren ajanları kullanan hastalar plazma alüminyum düzeyi açısından belirli aralıklarla izlenmelidir (35).

\section{Mineraller}

\section{Fosfor}

Glomerüler filtrasyon hızı $\leq 25$ mL/dakika olduğunda, diyetle fosfor alımı kısıtlanmadığı zaman hiperfosfatemi görülür. Bununla birlikte, KBH'ye eşlik eden kemik bozukluklarından dolayı iskelet sistemi fosforu kontrol edemediği için hiperfosfatemi durumuna katkıda bulunur (37). Hafif böbrek yetmezliği olan hastalarda fosfor alımının azalması, paratiroid hormon (PTH) düzeyini azaltır ve iskelet yanıtını arttırır (38). Hiperfosfatemi, kemik ve mineral bozuklukları ile kardiyovasküler hastalık morbidite ve mortalitesinin artışına neden olur (39).

Yüksek fosfat alımı, erken dönem KBH'de her zaman hiperfosfatemiye neden olmasa da, sekonder hiperparatiroidizm için risk etmenidir. Diyaliz tedavisi almayan Evre 3 ve 5 KBH'li bireylerde en uygun PTH düzeyi bilinmemekle birlikte, PTH'nin üst limitin üzerinde çıkması veya sürekli artması durumlarında, hiperfosfatemi, hipokalsemi, yüksek fosfat alımı, D vitamini eksikliği gibi değiştirilebilir etmenlerin değerlendirilmesi ve tek başına veya diğer tedavilere ek olarak diyet fosfor alımının sinırlandırılması önerilmektedir (22).

Gastrointestinal sistemden fosfor emilimi fosfat bağlayıcı ajanların kullanılmasıyla azaltılabilir. Protein alımını azaltarak, temel fosfor kaynakları olan et ve süt ürünlerini sinırlandırarak, diyet fosforu düşürülebilir (Tablo 3) $(25,38)$.

\section{Magnezyum}

Böbrek işlevi azaldıkça serum magnezyum düzeyi yükselir. Orta düzeyde böbrek yetmezliğinde (GFH >30 mL/dakika) magnezyum düzeyi, magnezyum atımındaki artışla dengelenebilir. Böbrek işlevi kötüleştiğinde ve Evre 5 KBH'ye yaklaşıldığında dengeleyici mekanizmalar yetersiz kalır ve hipermagnezemi gelişebilir (40). Hipermagnezemi derecesi artarsa, aritmi, solunum hızında ve kan basincında azalma sık görülür. Serum magnezyum düzeyi $10 \mathrm{mg} / \mathrm{dL}$ 'yi aşarsa genellikle şiddetli hipotansiyon ve mental depresyon gözlenir. Bu değer $15 \mathrm{mg} / \mathrm{dL}$ ye yükseldiğinde koma ve ölüm meydana gelebilir (41).

Hipermagnezemi, ileri derecede böbrek yetmezliğinin bir belirtisidir. GFH'ı >15 mL/dakika olan hastalarda seyrek olarak hipermagnezemi gözlenir. GFH 10 $\mathrm{mL} /$ dakika'ya düştüğünde hafif, GFH $<5 \mathrm{~mL} /$ dakika olduğunda belirgin hipermagnezemi ortaya çıkar. Bununla birlikte, tiyazid diüretikler, proton-pompa inhibitörleri, sisplatin, aminoglukozid antibiyotikler ve kalsinörin inhibitörleri gibi farklı ilaçların yan etkisi olarak, diyaliz alan KBH ve son dönem böbrek yetmezliği olan hastalarda serum magnezyum düzeyleri normal veya düşük olabilir (42).

\section{Kalsiyum}

Vücut kalsiyum dengesinin sağlanmasında diyetle alınan kalsiyum miktarı, kalsiyum emiliminin düzenlenmesinde D vitamini ve metabolitleri önemli bir rol oynar. Düşük kalsiyumlu diyetle beslenen bir hastada, iyonize kalsiyum düzeyindeki hafif bir azalma PTH salınıminı tetikler, bu da 25(OH) $\mathrm{D}_{3}$ 'ün $1,25(\mathrm{OH})_{2} \mathrm{D}_{3}$ 'e dönüşümünü arttırır. $\mathrm{Bu}$ metabolit, kalsiyum dengesini yeniden sağlamak için gastrointestinal sistemden kalsiyum emilimini arttırır. Bununla birlikte, tirokalsitonin, büyüme hormonu, tiroid hormonu, minerakokortikoidler ve glukokortikoidler gibi diğer hormonlar da idrarda kalsiyum atımını arttırır. Metabolik asidoz renal kalsiyum emilimini azaltır (41). 
Böbrek işlevi bozulmamış bireylerde, vücut gereksinmesini aşan kalsiyum idrarla atılırken, KBH durumunda böbrek işlevlerini yeterli düzeyde gerçekleştirememektedir (43). Kronik böbrek hastalığında pozitif kalsiyum dengesinde vasküler kalsifikasyon ve kardiyovasküler olay riski artarken, negatif kalsiyum dengesinde osteoporozis ve kırık riski artmaktadır (44). Tedavi edilmeyen KBH'de D vitamini eksikliği nedeniyle gastrointestinal kalsiyum alımında azalmaya bağlı görülen hipokalsemi, sekonder hiperparatiroidizm ve renal osteodistrofi patogenezinde rol oynar (22).

Kronik böbrek hastalığında, kemik ve mineral bozukluklarının tanısı için 3. evreden başlayarak serum kalsiyumunun yanı sira serum fosfat, PTH, alkalen fosfataz aktivitesinin rutin olarak izlenmesi önerilmektedir (22). Günde 800-1000 mg kalsiyum tüketilmesinin, KBH'li bireylerde kalsiyum dengesinin sağlanacağı belirtilmektedir (Tablo 3) $(25,44)$.

Tablo 3. Yetişkinlerde KBH evresine göre bazı minerallerin önerilen alım düzeyleri (28)

\begin{tabular}{|c|c|c|c|c|c|}
\hline Mineral & $\begin{array}{c}\text { Artmış KBH riski } \\
\text { ile normal } \\
\text { böbrek işlevi } \\
\text { (GFH >60 } \\
\text { mL/dakika) }\end{array}$ & $\begin{array}{c}\text { Hafif-orta düzey } \\
\text { KBH } \\
\text { (GFH 30-60 } \\
\text { mL/dakika) }\end{array}$ & $\begin{array}{c}\text { İlerlemiş KBH } \\
\text { (GFH<30 } \\
\text { mL/dakika) }\end{array}$ & Diyalize geçiş & $\begin{array}{c}\text { Devam eden } \\
\text { diyaliz veya } \\
\text { protein-enerji } \\
\text { kaybının olduğu } \\
\text { herhangi bir evre }\end{array}$ \\
\hline$\overline{\text { Fosfor (mg/gün)* }}$ & $\begin{array}{l}<1000 \text {, koruyucu } \\
\text { maddelere ve } \\
\text { işlenmiş besinlere } \\
\text { eklenen inorganik } \\
\text { fosforu en aza } \\
\text { indirin. }\end{array}$ & $\begin{array}{c}\text { <800, eklenmiş } \\
\text { inorganik fosforu } \\
\text { en aza indirin ve } \\
\text { daha fazla bitkisel } \\
\text { kaynaklı besin } \\
\text { tüketimini teşvik } \\
\text { edin. }\end{array}$ & $\begin{array}{c}<800, \text { eklenmiş } \\
\text { inorganik fosforu } \\
\text { en aza indirin ve } \\
\text { daha fazla bitkisel } \\
\text { kaynaklı besin } \\
\text { tüketimini teşvik } \\
\text { edin. }\end{array}$ & $\begin{array}{l}\text { <800, eklenmiş } \\
\text { inorganik fosforu } \\
\text { en aza indirin ve } \\
\text { fosfor bağlayıcl } \\
\text { düşünün. }\end{array}$ & $\begin{array}{l}\text { <800, eklenmiş } \\
\text { inorganik fosforu } \\
\text { en aza indirin, } \\
\text { gerektiğinde fosfor } \\
\text { bağlayıcı ekleyin. }\end{array}$ \\
\hline Kalsiyum (mg/gün) & $\begin{array}{l}\text { 1000-1300 } \\
\text { (yaşa göre } \\
\text { düzeltilmiş) }\end{array}$ & $800-1000$ & $800-1000$ & $\begin{array}{c}800-1000 \text { veya daha } \\
\text { az }\end{array}$ & $<800$ \\
\hline Potasyum (g/gün) $\dagger$ & $\begin{array}{c}4.7 \text { (genel } \\
\text { popülasyon için } \\
\text { önerilen ile aynı) }\end{array}$ & $\begin{array}{c}4.7 \text { sık veya şiddetli } \\
\text { hiperkalemi } \\
\text { dalgalanmaları } \\
\text { olmadığı sürece }\end{array}$ & $\begin{array}{c}<3 \text {, yüksek posa } \\
\text { alımı sırasında } \\
\text { sık hiperkalemi } \\
\text { görülürse }\end{array}$ & $\begin{array}{l}<3 \text {, yüksek posa } \\
\text { alımı sırasında } \\
\text { sık hiperkalemi } \\
\text { görülürse }\end{array}$ & $\begin{array}{l}<3 \text {, yüksek posa } \\
\text { alımı hedefleyin. }\end{array}$ \\
\hline
\end{tabular}

*Hiperfosfatemi açısından hastanın durumuna bakılmaksızın diyet fosforu sinırlandırılmalıdır.

† Periton diyalizi alan ve hipokalemisi olan hastalarda potasyum alımı arttırllmalıdır.

\section{Potasyum}

Kronik böbrek hastalığında, hiperkalemi (serum potasyum $\geq 5 \mathrm{mEq} / \mathrm{L}$ ) prevalansı \%14-20, hipokalemi (serum potasyum $\leq 4 \mathrm{mEq} / \mathrm{L}$ ) prevalansı ise \%12-18 arasında değişmektedir. Kronik böbrek hastalığında hiperkaleminin gelişmesinde temel risk etmenleri, düşük GFH, anjiotensin-dönüştürücü enzim inhibitörleri/anjiotensin reseptör blokerleri, düşük beden kütle indeksi (BKI), düşük serum bikarbonat düzeyleri, erkek cinsiyet, diyabet, malignite iken hipokalemi için bu etmenler, diüretikler, kadın cinsiyet, yüksek BKİ ve malignitedir (45).
Hem hipokalemi hem de hiperkalemi mortalite artışı ile ilişkilidir. Aşırı potasyum kısıtlaması, kronik hipertansiyonun şiddetlenmesine, intradiyalitik hipotansiyona, ventriküler aritmiye, renal fibrozise ve kist oluşumuna neden olabilir. Fazla potasyum alımı ise hiperkalemiye, hiperfosfatemiye, üremik nöropati gelişimine yol açabilir. Bu bağlamda, böbrek hastalarının öğün planı yapılırken hem hipokalemi hem de hiperkalemi riski göz önünde bulundurulmalıdır (46). Amerika Ulusal Böbrek Vakf,, serum potasyum düzeyinin 3.5-5.0 $\mathrm{mEq} / \mathrm{L}$ olmasını önermektedir (47). 


\section{Sodyum}

Kronik böbrek hastalığında sodyum tutulumu, ödem ve hipertansiyon gibi sorunlara yol açarak, böbrek damar yapısını değiştiren oksidatif stresi arttırır (48).

Bir meta-analiz çalışmasında, günlük sodyum alımını 179 mEq'den (4117 mg) 104 mEq'e (2392 mg) düşürmenin, sistolik kan basıncını 5 mmHg, diyastolik kan basıncını 2 mmHg azalttığı saptanmıştır (49). Sodyum kisıtlaması, KBH'nın ilerlemesini önlemede etkili bir yöntemdir (48). Kontrendikasyon olmadıkça, tuz alımının azaltılması, günlük sodyum alımının $<2$ g (5 g tuz) olması önerilmektedir (27). Ulusal Böbrek Hastalıkları Eğitim Programı rehberi ise günlük sodyum alımının <2.3 g olmasını önermektedir (50). Farklı öneriler bulunmakla birlikte sodyum alımı, böbrek hastalığı olan bireyin klinik bulguları ve gereksinmeleri göz önünde bulundurularak planlanmalıdır.

\section{SONUÇ VE ÖNERILLER}

Kronik böbrek hastalığında ve diyaliz gerektiren son dönem böbrek yetmezliğinde mikro besin ögesi bozukluklarına yönelik yeterli veri olmamakla birlikte, plazma ve doku düzeylerinde değişikler olabildiği için son zamanlarda bu konuya artan bir ilgi vardır. $\mathrm{Bu}$ hasta popülasyonunun mikro besin ögesi durumunu araştıran iyi tasarlanmış çalışmalar yapılmalıdır. Özellikle $\mathrm{KBH}$ hastalarının mikro besin ögesi gereksinmelerini daha iyi anlamak ve diyet müdahaleleri ile sağlık durumunu iyileştirme stratejileri oluşturmak için bu durum oldukça önemlidir.

Çıkar çatışması - Conflict of interest: Yazarlar çıkar çatışması olmadığını beyan ederler. - The authors declare that they have no conflict of interest.

\section{KAYNAKLAR}

1. Jankowska M, Rutkowski B, Debska-Slizien A. Vitamins and microelement bioavailability in different stages of chronic kidney disease. Nutrients 2017;9(3):1-8.

2. Steiber AL, Kopple JD. Vitamin status and needs for people with stages 3-5 chronic kidney disease. J Ren Nutr 2011;21(5):355-68.
3. Clase CM, Ki V, Holden RM. Water-soluble vitamins in people with low glomerular filtration rate or on dialysis: a review. Semin Dial 2013;26(5):546-67.

4. Institute of Medicine: For Thiamin, riboflavin, niacin, vitamin $\mathrm{B}_{6}$, folate, $\mathrm{B}_{12}$, pantothenic acid, biotin/choline. Washington DC: National Academy Press; 2000.

5. Saka Y, Naruse T, Kato A, Tawada N, Noda Y, Mimura $\mathrm{T}$, et al. Thiamine status in end-stage chronic kidney disease patients: a single-center study. Int Urol Nephrol 2018;50(10):1913-8.

6. Porrini M, Simonetti P, Ciappellano S, Testolin G, Gentile MG, Manna G, et al. Thiamin, riboflavin and pyridoxine status in chronic renal insufficiency. Int J Vitam Nutr Res 1989;59(3):304-8.

7. Taketani Y, Masuda M, Yamanaka-Okumura H, Tatsumi S, Segawa H, Miyamoto K, et al. Niacin and chronic kidney disease. J Nutr Sci Vitaminol (Tokyo) 2015;61(Suppl):173-5.

8. Streja E, Kovesdy CP, Streja DA, Moradi H, KalantarZadeh K, Kashyap ML. Niacin and progression of CKD. Am J Kidney Dis 2015;65(5):785-98.

9. Jin Kang H, Kim DK, Mi Lee S, Han Kim K, Hee Han S, Hyun Kim K, et al. Effects of low-dose niacin on dyslipidemia and serum phosphorus in patients with chronic kidney disease. Kidney Res Clin Pract 2013;32(1):21-6.

10. Corken $M$, Porter J. Is vitamin $B_{6}$ deficiency an underrecognized risk in patients receiving haemodialysis? A systematic review: 2000-2010. Nephrology (Carlton) 2011;16(7):619-25.

11. Fouque D, Vennegoor M, Ter Wee P, Wanner C, Basci A, Canaud B, et al. EBPG guideline on nutrition. Nephrol Dial Transplant 2007;22 (Suppl2):45-87.

12. Hassan K. Association of low potassium diet and folic acid deficiency in patients with CKD. Ther Clin Risk Manag 2015;11:821-7.

13. Kayabaşı H, Şit D, Köz S, Şahin İ, Yılmaz ME. Kronik böbrek hastalığında mikrobesinler ve anemi. Türkiye Klinikleri J Nephrol-Special Topics 2012;5(2):36-43.

14. Cianciolo G, De Pascalis A, Di Lullo L, Ronco C, Zannini C, La Manna G. Folic acid and homocysteine in chronic kidney disease and cardiovascular disease progression: Which comes first? Cardiorenal Med 2017;7(4):255-66.

15. Gavriilaki E, Paschou E, Kalaitzoglou A, Papaioannou G, Sabanis N. $\mathrm{B}_{12}$ deficiency in chronic kidney disease: early recognition matters. Intern Med J 2015;45(11):1195-6.

16. Richter A, Kuhlmann MK, Seibert E, Kotanko P, Levin NW, Handelman GJ. Vitamin C deficiency and secondary hyperparathyroidism in chronic haemodialysis patients. Nephrol Dial Transplant 2008;23(6):2058-63.

17. Sirover WD, Liu Y, Logan A, Hunter K, Benz RL, Prasad D, et al. Plasma ascorbic acid concentrations in prevalent 
patients with end-stage renal disease on hemodialysis. J Ren Nutr 2015;25(3):292-300.

18. Handelman GJ, Levin NW. Guidelines for vitamin supplements in chronic kidney disease patients: what is the evidence? J Ren Nutr 2011;21(1):117-9.

19. Kumar VA, Kujubu DA, Sim JJ, Rasgon SA, Yang PS. Vitamin D supplementation and recombinant human erythropoietin utilization in vitamin D-deficient hemodialysis patients. J Nephrol 2011;24(1):98-105.

20. Jean G, Souberbielle JC, Chazot C. Vitamin D in chronic kidney disease and dialysis patients. Nutrients 2017;9(4):1-15.

21. Keung L, Perwad F. Vitamin D and kidney disease. Bone Rep 2018;9:93-100.

22. Eknoyan G, Lameire M, Kasiske B. Kidney Disease: Improving Global Outcomes (KDIGO) CKD-MBD Update Work Group. KDIGO 2017 clinical practice guideline update for the diagnosis, evaluation, prevention, and treatment of chronic kidney disease-mineral and bone disorder (CKD-MBD). Kidney Int Suppl 2017;7:1-59.

23. Galli F, Buoncristiani U, Conte C, Aisa C, Floridi A. Vitamin $\mathrm{E}$ in uremia and dialysis patients. Ann N Y Acad Sci 2004;1031:348-51.

24. Steiber AL. Chronic kidney disease: considerations for nutrition interventions. J Parenter Enteral Nutr 2014;38(4):418-26.

25. Kalantar-Zadeh K, Fouque D. Nutritional management of chronic kidney disease. N Engl J Med 2017;377(18):176576.

26. Babitt JL, Lin HY. Mechanisms of anemia in CKD. J Am Soc Nephrol 2012;23(10):1631-4.

27. Eknoyan G, Lameire M, Eckardt KU. Kidney Disease: Improving Global Outcomes (KDIGO) Anemia Work Group. KDIGO clinical practice guideline for anemia in chronic kidney disease. Kidney Inter Suppl 2012;2:279335.

28. Yip R, Dallman PR. Iron. In: Ziegler EE, Filer LJ, editors. Present Knowledge of Nutrition. 7th ed. Washington DC: ILSI Press; 1996. p.277-92

29. Bhogade RB, Suryakar AN, Joshi NG. Effect of hemodialysis on serum copper and zinc levels in renal failure patients. EJGM 2013;10(3):154-7.

30. Kung WJ, Shih CT, Lee CH, Lin CC. The divalent elements changes in early stages of chronic kidney disease. Biol Trace Elem Res 2018;185(1):30-5.

31. Shih CT, Shiu YL, Chen CA, Lin HY, Huang YL, Lin CC. Changes in levels of copper, iron, zinc, and selenium in patients at different stages of chronic kidney disease. GMBHS 2012;4(4):128-30.

32. Kasama RK. Trace minerals in patients with end-stage renal disease. Semin Dial 2010;23(6):561-70.
33. Lobo JC, Aranha LN, Moraes C, Brito LC, Mafra D. Linking zinc and leptin in chronic kidney disease: future directions. Biol Trace Elem Res 2012;146(1):1-5.

34. Sedighi O, Zargari M, Varshi G. Effect of selenium supplementation on glutathione peroxidase enzyme activity in patients with chronic kidney disease: a randomized clinical trial. Nephrourol Mon 2014;6(3):17945.

35. Alfrey AC. Aluminum toxicity in patients with chronic renal failure. Ther Drug Monit 1993;15(6):593-7.

36. Cannata JB, Olaizola IR, Gomez-Alonso C, MenendezFraga P, Alonso-Suarez M, Diaz-Lopez JB. Serum aluminum transport and aluminum uptake in chronic renal failure: role of iron and aluminum metabolism. Nephron 1993;65(1):141-6.

37. Kovach K, Hruska KA. Hyperphosphatemia. In: Jacobson HR, Striker GE, Klahr S, editors. The Principles and Practice of Nephrology. 2nd ed. St. Louis: Mosby; 1995. p.1000-5.

38. Delmez JA, Slatopolsky E. Hyperphosphatemia: its consequences and treatment in patients with chronic renal disease. Am J Kidney Dis 1992;19(4):303-17.

39. Spasovski G, Massy Z, Vanholder R. Phosphate metabolism in chronic kidney disease: from pathophysiology to clinical management. Semin Dial 2009;22(4):357-62.

40. Massy ZA, Nistor I, Apetrii M, Brandenburg VM, Bover $\mathrm{J}$, Evenepoel P, et al. Magnesium-based interventions for normal kidney function and chronic kidney disease. Magnesium Res 2016;29(4):126-40.

41. Bogden JD, Klevay LM. Clinical Nutrition of the Essential Trace Elements and Minerals: the Guide for Health Professionals. New York: Humana Press; 2000.

42. Van de Wal-Visscher ER, Kooman JP, Van der Sande FM. Magnesium in chronic kidney disease: should we care? Blood Purif 2018;45(1-3):173-8.

43. Bushinsky DA. Clinical application of calcium modeling in patients with chronic kidney disease. Nephrol Dial Transplant 2012;27(1):10-3.

44. Hill Gallant KM, Spiegel DM. Calcium balance in chronic kidney disease. Curr Osteoporos Rep 2017;15(3):214-21.

45. Gilligan S, Raphael KL. Hyperkalemia and hypokalemia in CKD: Prevalence, risk factors, and clinical outcomes. Adv Chronic Kidney Dis 2017;24(5):315-8.

46. Sinha AD, Agarwal R. Chronic renal disease progression: treatment strategies and potassium intake. Semin Nephrol 2013;33(3):290-9.

47. National Kidney Foundation-NKF. Potassium and your CKD diet. 2017. Available at: https://www.kidney.org/ atoz/content/potassium Accessed January 17, 2019. 
48. Soi V, Yee J. Sodium homeostasis in chronic kidney disease. Adv Chronic Kidney Dis 2017;24(5):325-31.

49. Garofalo C, Borrelli S, Provenzano M, De Stefano T, Vita C, Chiodini P, et al. Dietary salt restriction in chronic kidney disease: A meta-analysis of randomized clinical trials. Nutrients 2018;10(6):e732.
50. National Kidney Disease Education Program/NKDEP. Sodium tips for people with chronic kidney disease (CKD). NIH Publication No. 14-7407. June 2014. Available at: https://www.nutrition.va.gov/docs/UpdatedPatientEd/ Sodium Tips_For_CKD.pdf Accessed January 17, 2019. 